\title{
Anticancer activity of the "Hardaliye" on HT-29 Cell Line and proliferative activity on CF-1 cell line: Apoptosis and Antioxidant pathway responsive gene expressions
}

\author{
Ozge Kahraman Ilıkkan ${ }^{1 *}$, Oguzhan Doganlar ${ }^{1,2}$, Zeynep Banu Doganlar ${ }^{2}$, Pınar Altınoluk Mimiroğlu ${ }^{1}$ and Asude Soykan Kırbaş ${ }^{1}$ \\ ${ }^{1}$ Trakya University, Technology Research and Development Center, Balkan Campus, Edirne, Turkey \\ ${ }^{2}$ Trakya University, Faculty of Medicine, Department of Medical Biology, Balkan Campus, Edirne, Turkey
}

\begin{abstract}
The study was designed to detect anticancer activity and proliferative effect of the Hardaliye in HT-29 and CF-1 cell lines, respectively. Based on MTT results, two dilutions namely, five (H5) and ten-fold (H10) were selected for further analyses. Apoptosis and antioxidant pathway related gene expression levels were detected using qRT-PCR and tali apoptosis assay was used to screen percentage levels of death, apoptotic and viable cells after $24 \mathrm{~h}$ and $48 \mathrm{~h}$ of treatment.

Results suggested that Hardaliye was effective on cancer cells and trigger apoptosis via increase of Bax (22.45 \pm 3.1 -fold for H5 and 6.49 \pm 0.1 -fold for H10) as well as SOD and CAT activity. However, Hardaliye also affected slightly healthy cells when diluted fivefold, though, did not affect when dilute tenfold. According to gene expression levels, an increase at antioxidant enzyme and apoptosis inhibitors was seen after $24 \mathrm{~h}$. On the other hand, antioxidant enzymes apart from GpX of $\mathrm{H} 5$, decreased after 48h. Predictably, antioxidant substances of Hardaliye revealed an antioxidant activity over time.

Overall, this was the first report considering anticancer activity of Hardaliye besides its efficacy on healthy cells. In this respect, these preliminary results can indicate potential of Hardaliye as a food support in preventing colon cancer.
\end{abstract}

\section{Abbreviations}

DR: Death receptor; Fas: Fatty Acid Synthase; XIAP: X-linked inhibitor of apoptosis; BAX: BCL-2-associated X protein; BCL-2: B-cell leukemia 2; Cyct c: Cytochrom c; IAP: Inhibitor of apoptosis protein; HSP: Heat Shock Protein; Sod: Super oxide dismutase; GpX: Glutathion Peroxidase; Casp: Caspase

\section{Introduction}

Cancer therapy is a worldwide concern. Apart from chemical agent, there is research on natural products as well as food components. Accordingly, grape and its derivatives besides mustard seeds are good sources of phenolic compounds such as gallic acid, resveratrol and flavonoids, including catechin, quercetin which are beneficial for a wide variety of diseases as well as cancer. In fact, in vivo studies have shown that phenolic compounds and anthocyanidins diminish growth of colorectal cancer. Feeding mice with grape seed extract which is rich source of anthocyanidins at a dose of $200 \mathrm{mg} / \mathrm{kg}$ has been demonstrated to decrease colorectal tumor $44 \%$ in volume after 8 weeks of treatment and also induce apoptosis and cell cycle arrest of colon cancer. In addition, in rats fed with resveratrol orally at a dose of $60 \mathrm{mg} / \mathrm{kg}$ for 49 days, precancerous colonic lesions decreased [1-4].

Hardaliye is a popular non-alcoholic and traditional beverage of Thrace region produced from grape, mustard seeds, sour cherry leaves and it is fermented by lactic acid bacteria for 5-10 days. Hardaliye is well known with benefits for anemia, cardiac diseases and thought that it is also beneficial for cancer [5-7].

Defects in the apoptosis pathway cause to the development of malignity due to the lack of the programmed cell death which protects cell from effects of mutations and provides physiological growth control as well as tissue homeostasis [8]. Two major apoptosis signaling pathway exist in cells, namely: i) intrinsic which occurs in mitochondria and ii) extrinsic pathway. The latter is induced by death receptors which belong to TNF (Tumor Necrosis Factor) receptor super family such as TNF- $\alpha$, DR 4, DR 5, Fas (CD 95) $[9,10]$ and afterwards induces activity of caspase 8 and caspase 3 which are initiator and effector caspases, recpectively [11,12]. However, stimuli such as anticancer drugs trigger intrinsic pathway through differentiation of the mitochondrial permeability. Subsequently cytochrome $\mathrm{c}$ is released and apoptosome formation is initiated [13]. Also, the intrinsic pathway includes pro-apoptotic and anti-apoptotic proteins belonging to $\mathrm{Bcl}$ 2 protein family. Of this family, Bax induces apoptosis by promoting cytochrome c release while Bcl-2 inhibits [14]. Additionally, activation of caspases such as casp-3 and casp- 9 is disrupted by inhibitor of apoptosis proteins (IAps) such as c-IAP1 (BIRC2), c-IAP2 (BIRC3), X-linked IAP (XIAP, BIRC4), Survivin (BIRC5) [13,15].

Antioxidant enzymes such as superoxide dismutases (SODs), glutathione peroxidases (GPXs), glutathione transferase (GST) and

Correspondence to: Ozge Kahraman Ilıkkan, $\mathrm{PhD}$, Trakya University, Technology Research and Development Center, Balkan Campus, Edirne, Turkey, Tel: +90 284 2357653; Fax: +90 284 2360357; E-mail: mikro_ozge@yahoo.com

Key words: apoptosis, cancer prevention, cell biology, colorectal cancer, gene expression, polyphenols

Received: June 02, 2017; Accepted: June 27, 2017; Published: June 30, 2017 
Ilıkan Kahraman O (2017) Anticancer activity of the "Hardaliye" on HT-29 Cell Line and proliferative activity on CF-1 cell line: Apoptosis and Antioxidant pathway responsive gene expressions

catalase (CAT) provide a defense against harmful effect of these molecules by converting them to non-toxic molecules. However, antioxidant substances and elements such as selenium and zinc are nonenzymatic antioxidants and they neutralize harmful effect of these free radicals $[16,17]$. On the other hand, a heatschock protein HSP 70 , protects cells in response to adverse effects of stress conditions. However, an overexpression of Hsp 70 is seen in tumor cells and Hsp 70 inhibits apoptosis in both intrinsic and extrinsic pathways. Thereby, Hsp 70 has recently become a marker for prognosis and a pharmological target which its inhibitors have been researched [8-21].

Herein, primarily, we determined the phenolic and metal content of Hardaliye, later on, the effect of the Hardaliye on apoptosis pathway and antioxidant responsive gene expressions of colon cancer cell line (HT-29) as well as proliferative effect on mouse embryonic fibroblast (CF-1) was evaluated. This is the first report on anti-cancer activity of the Hardaliye, although a few studies are available on anticancer effect of grape seed or phenolic compounds on colon cancer or other cancer types [22]. Results of this study demonstrated that Hardaliye reduced viability and triggered apoptosis of HT-29 cancer cells. Hardaliye blocked apoptosis via apoptosis inhibitors in healthy cells and decreased most of oxidative stress related gene expressions.

\section{Material and methods}

\section{Chemicals, standards and reagents}

Formic acid (98-100\%), methanol (Hypergrade LC MS), isopropyl alcohol (2-Propanol) and DMSO were purchased from Merck, Darmstadt, Germany. Ammonium formate (HPLC grade) was from Sigma-Aldrich, Germany. Reference standards; gallic acid, catechin, 2-5 dihydroxybenzoic acid, trans caffeic acid, syringic acid, trans sinapic acid, trans-p-coumaric acid, trans ferulic acid, resveratrol, salicylic acid were from Fluka while protocatechuic acid was purchased from HWI Analytik Gmbh, Germany. MTT (3(4, 5-dimethylthiazol-2yl)-2, 5-diphenyltetrazo-lium-bromide) was purchased from Biomatik Cambridge, Ontario. Phosphate buffer saline (PBS) and molecular biology grade water were from Gibco, Invitrogen, Carlsbad, CA, USA. The resistance of ultra-distilled water used for instrumental analysis was $18.2 \mathrm{M} \Omega$.

\section{Sample preparation}

Commercially obtained Hardaliye sample was centrifuged at 15.000 $\mathrm{g}$ for $30 \mathrm{~min}$ and filtered with a PTFE syringe filter $(0.22 \mu \mathrm{m}$ pore size). Hardaliye was diluted twofold with 50\% UPW; 25\% isopropanol, 25\% methanol and mixed with a mixing block for $2 \mathrm{~h}$., then, diluted fivefold with mobile phase A. Samples were transferred to amber vials. Analysis was repeated three times and presented as mean \pm SD.

\section{Liquid chromatography and mass spectrometry conditions}

Phenolic compounds were detected on Agilent 1260 infinity LC in combination with the Agilent 6460 Triple Quadrupole MS/MS System equipped with Jet Stream Electrospray ionization source (Agilent Technologies, Palo Alto, CA, USA). The analytical column was Agilent Poroshell $120 \mathrm{EC}-\mathrm{C}_{18}(4.6 \times 50 \mathrm{~mm}, 2.7 \mu \mathrm{m}$ particle size $)$ and set at $25^{\circ} \mathrm{C}$. Mobile Phase A consisted of UPW, $0.2 \%$ ammonium formate $(\mathrm{v} / \mathrm{v})$, $0.2 \%$ formic acid (v/v). Mobile Phase B consisted of metanol, $0.2 \%$ ammonium formate $(\mathrm{v} / \mathrm{v}), 0.2 \%$ formic acid $(\mathrm{v} / \mathrm{v})$. Flow rate was 0.3 $\mathrm{ml} / \mathrm{min}$ under ambient temperature. The injection volume was $1 \mu \mathrm{l}$ and the LC gradient conditions were as follows: 0 to $1 \mathrm{~min}, 70 \% \mathrm{~A}, 30 \% \mathrm{~B}$; 3 to $7 \mathrm{~min}$; $30 \%, 70 \%$; 9 to $10 \mathrm{~min}$. $50 \% \mathrm{~A}, 50 \% \mathrm{~B} ; 11$ to $12 \mathrm{~min} ; 70 \% \mathrm{~A}$, $30 \% \mathrm{~B}$. The run time was $12 \mathrm{~min}$.

The optimized MS parameters of analysis were as follows: Gas temperature was set at $325^{\circ} \mathrm{C}$, the nebulizer gas pressure was set at $45 \mathrm{psi}$, the nozzle voltage was set at $500 \mathrm{~V}$, the capillary monitoring (MRM) was performed in the positive and negative ion mode.

Data acquisition was carried out with Mass Hunter (version B.06.01) software. Collision energy, fragmentor voltage, precursor ion, product ion and polarity were presented in Table 1 . Nitrogen $\left(\mathrm{N}_{2}\right)$ was used as the collision gas 1.12 mTorr.

Calibration standard mixes were prepared in 50\% UPW, 25\% methanol, 25\% isopropanol and at the calibration concentration ranging from 1 to $200 \mathrm{ng} / \mathrm{mL}$.

\section{Metals in hardaliye by inductively coupled plasma-mass spectrometry (ICP-MS)}

Hardaliye sample filtered with $0.22 \mu \mathrm{m}$ PTFE syringe filter was diluted hundredfold with UPW and metal content was detected using ICP-MS (Agilent 7700x, Agilent Technologies, USA). Operating conditions of the ICP-MS were as follows: nebulizer gas flow $0.91 \mathrm{~L} /$ min, radio frequency (RF) $1200 \mathrm{~W}$, lens voltage $1.6 \mathrm{~V}$, cool gas $13.0 \mathrm{~L} /$ $\mathrm{min}$, and auxiliary gas $0.70 \mathrm{~L} / \mathrm{min}$.

\section{HT-29 and CF-1 (MEF) cell culture and the treatment of the hardaliye}

Human HT-29 cell culture line and Mouse embryonic fibroblast cells (MEF) were purchased from ATCC (Manassas,VA,USA). Cells were initially cultured in $75 \mathrm{~cm}^{2}$ flasks with DMEM (Dulbecco's Modified Eagle's medium) supplemented with 10\% FBS and Penicillin/ Streptomycin (100 IU/100 $\mu \mathrm{g} / \mathrm{ml}$ ) (Wisent Inc., Canada) and grown at $37^{\circ} \mathrm{C}$ in the presence of $5 \% \mathrm{CO}_{2}$ until $70-80 \%$ confluent. Cells were trypsinized at $37^{\circ} \mathrm{C}$, washed with PBS and were seeded in 6- well plates

Table 1. Phenolic content in Hardaliye and the basic LC MS/MS parameters. Data are presented as mean \pm SD, $n=3$.

\begin{tabular}{|c|c|c|c|c|c|c|c|c|}
\hline Phenolic Compound & Concentration $(\mu \mathrm{g} / \mathrm{L})$ & $\mathbf{R}^{2}$ & Retention Time (min) & Transition & Fragmentor Voltage & Collision Energy & Polarity & Linear Regression Equation \\
\hline gallic acid & $6273 \pm 93$ & 0.9994 & 2.286 & $227.2[143.1]$ & 127 & 24 & Negative & $y=60.368200 * x+388.226380$ \\
\hline resveratrol & $2070 \pm 260$ & 0.9994 & 5.966 & $169.1[125.1]$ & 88 & 8 & Negative & $\mathrm{y}=13.743032 * x+14.968057$ \\
\hline trans caffeic acid & $1633 \pm 70$ & 0.9997 & 4.951 & $291.2[139.1]$ & 93 & 12 & Positive & $y=327.680539 * x+1408.910941$ \\
\hline catechin & $1438 \pm 93$ & 0.9997 & 2.519 & $193.1[134.1]$ & 83 & 32 & Negative & $\mathrm{y}=467.977964 * \mathrm{x}+712.899032$ \\
\hline salicylic acid & $1343 \pm 100$ & 0.9994 & 6.756 & $153.1[109.1]$ & 83 & 12 & Negative & $\mathrm{y}=228.229004 * \mathrm{x}+1137.887913$ \\
\hline trans- $p$-coumaric acid & $961 \pm 16$ & 0.9996 & 5.703 & $179.2[135.1]$ & 93 & 12 & Negative & $\mathrm{y}=308.850638 * \mathrm{x}+815.804776$ \\
\hline protocatechuic acid & $601 \pm 25$ & 0.9984 & 2.687 & $137.1[93.1]$ & 83 & 12 & Negative & $y=97.497135 * x+688.355588$ \\
\hline 2-5 dihydroxybenzoic acid & $582 \pm 23$ & 0.9996 & 2.463 & $223.2[208]$ & 101 & 16 & Negative & $\mathrm{y}=91.923631 * \mathrm{x}+1176.082779$ \\
\hline syringic acid & $117 \pm 13$ & 0.9995 & 5.023 & $163.2[119.1]$ & 86 & 12 & Negative & $\mathrm{y}=9.810302 * \mathrm{x}-8.343955$ \\
\hline trans ferulic acid & $20 \pm 1$ & 0.9995 & 5.772 & $153.1[108]$ & 91 & 20 & Negative & $\mathrm{y}=34.812488 * \mathrm{x}+44.103431$ \\
\hline trans sinapic acid & $19 \pm 6$ & 0.9993 & 5.668 & $197.2[182]$ & 86 & 8 & Negative & $y=25.763802 * x+72.277006$ \\
\hline
\end{tabular}


Ilıkan Kahraman O (2017) Anticancer activity of the "Hardaliye" on HT-29 Cell Line and proliferative activity on CF-1 cell line: Apoptosis and Antioxidant pathway responsive gene expressions

$\left(\sim 10^{6}\right.$ cell per well) for Tali apoptosis analysis as well as RNA isolation and in 96-well plates $(\sim 5000-10.000$ cell per well $)$ for MTT analysis. Exponentially growing cells were treated with Hardaliye which was filtered with a $0.22 \mu \mathrm{m}$ sterile syringe filter, by serially diluting 10 to 80 -fold for MTT assay, 5 and 10-fold for Tali apoptosis assay and qRTPCR. Each experiment has been repeated independently at least three times.

\section{MTT cell viability assay}

MTT (3(4, 5-dimethylthiazol-2-yl)-2,5-diphenyltetrazo-liumbromide) is an assay to determine viability of cells with the conversion of the water-soluble MTT to an insoluble purple formazan by respiring cells. MTT assay was carried out after $24 \mathrm{~h}$ and $48 \mathrm{~h}$ of experiment. $20 \mu \mathrm{l} \mathrm{MTT}\left(5 \mathrm{mg} / \mathrm{ml}\right.$ in PBS) was added and incubated at $37^{\circ} \mathrm{C}$ for 4h. Medium with MTT was carefully removed from all wells and the formazan crystals were dissolved with $200 \mu \mathrm{l}$ of DMSO and incubated at $37^{\circ} \mathrm{C}$ for $5 \mathrm{~min}$. Absorbance was recorded at $492 \mathrm{~nm}$ using MultiscanGo microplate reader (Thermo Scientific, USA). The viability\% was calculated [23]. The value that reduces absorbance $50 \%$ compared to untreated cells was assessed as IC 50.

\section{Annexin $\mathrm{V}$ and PI apoptosis analysis with $\mathrm{Tali}^{\mathrm{Tm}}$ image-based cytometer}

To assess apoptosis, cells were harvested with Trypsin/EDTA posttreatment $24 \mathrm{~h}$ and $48 \mathrm{~h}$. Tali apoptosis detection kit (Life Technologies, USA) protocol was followed according to manufacturer's instruction. Cells were stained with annexin-V Alexa Fluor ${ }^{\circledR} 488$ and PI (propidium iodide), incubated for $20 \mathrm{~min}$ and $5 \mathrm{~min}$ in the dark, respectively. 25 $\mu \mathrm{l}$ of stained cells were loaded into a Tali Cellular Analysis Slide. The viable, apoptotic and dead cells were analyzed using Tali image-based cytometer. Results were presented as mean \pm SD. The results were statistically analyzed after arcsine square root transformation.

\section{Total RNA isolation and cDNA synthesis}

All media was removed and $1 \mathrm{ml}$ of lizis buffer was added to cells. Total RNA was isolated according to manufacturer's instruction with PureLink ${ }^{\circledR}$ RNA Mini Kit (Life Technologies, USA). The RNA concentrations were determined by measuring UV absorbance at 260 $\mathrm{nm}$ with NanoQ (Pathtech, Australia). RNAs were equalized to $100 \mathrm{ng} /$ $\mu \mathrm{l}$ and reverse transcription was performed using High Capacity cDNA synthesis kit (Life Technologies, USA) on Veriti 96-Well Thermal Cycler system with the following protocol: step $1,25^{\circ} \mathrm{C}, 10 \mathrm{~min}$; step $2,37^{\circ} \mathrm{C}, 120 \mathrm{~min}$; step $3,85^{\circ} \mathrm{C}, 5 \mathrm{~min}$. RNA was stored at $-80^{\circ} \mathrm{C}$ while cDNA was stored at $-20^{\circ} \mathrm{C}$ for subsequent steps.

Detection of apoptosis and antioxidant related gene expressions using the $\mathrm{qRT}$ - PCR (Quantitative real-time PCR)

Expression levels of 19 genes related to apoptosis pathway, namely; tumour suppressor gene p53, apoptosis activator, Bax, apoptosis inhibitors, c-IAP 1, c- IAP2, Survivin (birc5), XIAP Bcl-2 and cyt c, Dr4, Dr5, Fas, Casp 2, Casp 9, Casp 3 as well as antioxidant related; Sod, Sod 2 (MnSOD), Cat, GpX, HSP 70 (Primers are listed in Table 3) were determined on ABI 7500 Fast qRT-PCR system (Life Technologies, USA) using following protocol: $20 \mu \mathrm{L}$ reactions containing $0.2 \mu \mathrm{M}$ each primer $(24,25), 10 \mu \mathrm{L}$ SYBR Select Master Mix (Life Technologies, USA) $(2 \mathrm{x})$ and $1.5 \mu \mathrm{L}$ template cDNA. After initial denaturation $1 \mathrm{x}$ $94^{\circ} \mathrm{C}$ for $3 \mathrm{~min}$; amplifications were performed for 40 cycles $94^{\circ} \mathrm{C}$ for $45 \mathrm{~s} ; 58^{\circ} \mathrm{C}$ for $45 \mathrm{~s}$; and $72^{\circ} \mathrm{C} 1 \mathrm{~min}$ and $1 \times 72^{\circ} \mathrm{C} 10 \mathrm{~min}$. GADPH mRNA expressions were used as housekeeping gene for normalization.
Relative fold-change of mRNA expression levels were determined by the Comparative CT method ( $2^{-\triangle \Delta C T}$ method) (26) and presented as mean $\pm \mathrm{SD}$. All reactions were set up in triplicates.

\section{Statistical analyses}

Differences between control and treatments were analyzed using a statistical software JMP 12.0 (SAS Institute, Cary, NC, USA) with oneway ANOVA followed by Tukey-Kramer multiple comparison test. Differences were considered significant at $p<0.05$ and specified with asterix as ${ }^{\star * *} \mathrm{p}<0.001,{ }^{\star *} \mathrm{p}<0.01,{ }^{\star} \mathrm{p}<0.05$.

\section{Results}

\section{Phenolic and metal content of hardaliye}

Gallic acid and resveratrol, which are naturally occur in grape and grape seed, were the highest in Hardaliye (Table 1). Additionaly, Hardaliye contained notably amount of potassium and magnesium as well as zinc and selenium which are antioxidant metals (Table 2). This was consistent with analyses performed with grape juice (27).

\section{Efficacy of hardaliye on HT-29 and CF-1 cells}

Cell viability and tali assay: The effect of Hardaliye was assessed after $24 \mathrm{~h}$ and $48 \mathrm{~h}$ of experiments. According to MTT assay, 10 and 20 fold diluted Hardaliye decreased viability of $\%$ cancer cells, namely; $58 \pm$ $3 \%$ and $62 \pm 5 \%$ after $24 \mathrm{~h}$ while $34 \pm 2 \%$ and $38 \pm 5 \%$ after $48 \mathrm{~h}$. However, percentage of healthy cells almost did not change, on the contrary, increased $20 \%$ after diluted 20, 40 and 80 fold. Correspondingly, according to Annexin V-PI results, the effect of $\mathrm{H} 10$ on cancer cells was $47 \pm 11 \%$ and $26 \pm 2 \%$ after $24 \mathrm{~h}$ and $48 \mathrm{~h}$, respectively. But, in this method, H5 $40 \%$ decreased viability of healthy cell even though this rate was $25 \%$ for HT-29. In addition, apoptosis level of cancer cells was triggered by Hardaliye while it was close to $1-3 \%$ in healthy cells.

IC50 was detected as 10 fold. The other experiments were carried out with 5 and 10 fold diluted Hardaliye which are expressed as $\mathrm{H} 5$ and H10 (Figures 1 and 2).

\section{Real time PCR and gene expression of apoptosis and antioxidant markers}

The first step was to understand effect of Hardaliye on intrinsic or extrinsic apoptosis pathway markers of HT-29 cells. Following treatment with two dilutions, H10 triggered DR5 $2.39 \pm 0.36$ fold and H5 triggered the FAS $3.39 \pm 1.02$ - fold after $48 \mathrm{~h}$. However, for both dilution, Bax increased drastically ( $22.45 \pm 3.1$-fold for $\mathrm{H} 5$ and $6.49 \pm 0.1$-fold for H10 after $48 \mathrm{~h}$ ) and H10 triggered casp3 but casp9 and casp2. However, H5 triggered p53 and cyctc levels after $48 \mathrm{~h}$. In addition, Bcl-2 also increased but still remained lower than Bax level and other apoptosis inhibitors, namely, Survivin, XIAP, CIAP 1, CIAP 2 remained significantly low (Figures 3 and 5) as compared to control.

As for CF-1 cells, Fas; $2.5 \pm 0.46$-fold, p53; $2.4 \pm 0.15$-fold, cytc;

Table 2. Metal content in Hardaliye. Data are presented as mean $\pm \mathrm{SD}, \mathrm{n}=3$.

\begin{tabular}{|c|c|c|c|c|c|}
\hline Metal & $\begin{array}{c}\text { Concentration } \\
(\boldsymbol{\mu g} / \mathbf{L})\end{array}$ & Metal & $\begin{array}{c}\text { Concentration } \\
(\boldsymbol{\mu g} / \mathbf{L})\end{array}$ & Metal & $\begin{array}{c}\text { Concentration } \\
(\boldsymbol{\mu g} / \mathbf{L})\end{array}$ \\
\hline $\mathrm{K}$ & $156656.73 \pm 1794$ & $\mathrm{Mn}$ & $190.03 \pm 5$ & $\mathrm{Cr}$ & $12.70 \pm 0$ \\
\hline $\mathrm{Mg}$ & $11476.99 \pm 261$ & $\mathrm{Zn}$ & $131.41 \pm 3$ & $\mathrm{Ni}$ & $12.6 \pm 0$ \\
\hline $\mathrm{Ca}$ & $3132.32 \pm 70$ & $\mathrm{Sr}$ & $67.20 \pm 4$ & $\mathrm{Sb}$ & $4.25 \pm 1$ \\
\hline $\mathrm{Na}$ & $2128.51 \pm 80$ & $\mathrm{Se}$ & $26.58 \pm 1$ & $\mathrm{Co}$ & $2.38 \pm 0$ \\
\hline $\mathrm{Fe}$ & $441.20 \pm 14$ & $\mathrm{Ag}$ & $23.34 \pm 2$ & $\mathrm{Cd}$ & $0.48 \pm 0$ \\
\hline $\mathrm{Al}$ & $234 \pm 3$ & $\mathrm{Cu}$ & $17.76 \pm 0$ & & \\
\hline
\end{tabular}


Ilkkan Kahraman O (2017) Anticancer activity of the "Hardaliye" on HT-29 Cell Line and proliferative activity on CF-1 cell line: Apoptosis and Antioxidant pathway responsive gene expressions

Table 3. Primer list.

\begin{tabular}{|c|c|c|c|}
\hline \multicolumn{4}{|c|}{ Primer list related to apoptosis and oxidative stress pathway } \\
\hline DR4 & $\begin{array}{c}\text { F: CAGAAC GTCCTGGAGCCTGTAAC } \\
\text { R: ATG TCC ATT GCC TGA TTC TTT GTG }\end{array}$ & SOD & $\begin{array}{l}\text { F:GTTCGGTGACAACACCAATG } \\
\text { R:GGAGTCGGTGATGTTGACCT }\end{array}$ \\
\hline DR5 & $\begin{array}{l}\text { F: GGGAAGAAGATTCTCCTGAGATGT G } \\
\text { R: ACATTGTCC TCAGCC CCAGGTCG }\end{array}$ & SOD2 & $\begin{array}{l}\text { F: CGTCACCGAGGAGAAGTACC } \\
\text { R: CTGATTTGGACAAGCAGCAA }\end{array}$ \\
\hline Fas & $\begin{array}{l}\text { F: TCTAACTTGGGGTGGCTTTGTCTTC } \\
\text { R: GTGTCATACGCTTTCTTTCCAT }\end{array}$ & CAT & $\begin{array}{l}\text { F: TACGAGCAGGCCAAGAAGTT } \\
\text { R: ACCTTGTACGGGCAGTTCAC }\end{array}$ \\
\hline BAX & $\begin{array}{l}\text { F: ATGGACGGGTCCGGGGAG } \\
\text { R: TCAGCCCATCTTCTTCCA }\end{array}$ & GpX & $\begin{array}{l}\text { F: CCAAGCCTCATCACCTGGTCT } \\
\text { R: TCGATGTCAATGGTCTGGAA }\end{array}$ \\
\hline BCL-2 & $\begin{array}{l}\text { F: CAGCTGCACCTGACG } \\
\text { R: ATGCACCTACCCAGC }\end{array}$ & HSP 70 & $\begin{array}{l}\text { F: CTTATCAGTGAAATTAAGCGAGAGC } \\
\text { R: ACAAGGATAACTTCATCAACCTTTG }\end{array}$ \\
\hline CytC & $\begin{array}{c}\text { F: TTTGGATCCAATGGGTGATGTTGAG } \\
\text { R: TTTGAATTCCTCATTAGTAGCTTTTTTGAG }\end{array}$ & Survivin & $\begin{array}{l}\text { F: GACGACCCCATAGAGGAACA } \\
\text { R: GACAGAAAGGAAAGCGCAAC }\end{array}$ \\
\hline Caspase-2 & $\begin{array}{l}\text { F: TGGCACTGATGGCAAACTCC } \\
\text { R: ATCGGAGCGTGTAGGCAAAC }\end{array}$ & c-IAP 1 & $\begin{array}{l}\text { F: GCATTTTCCCAACTGTCCAT } \\
\text { R: ATTCGAGCTGCATGTGTCTG }\end{array}$ \\
\hline Caspase- 3 & $\begin{array}{l}\text { F: GTGGAATTGATGCGTGATGT-3' } \\
\text { R: ACAGGTCCATTTGTTCCAAAA-3 }\end{array}$ & c-IAP 2 & $\begin{array}{l}\text { F: ATTTTCCACCACAGGCAAAG } \\
\text { R: GCATTTTCCCAACTGTCCAT }\end{array}$ \\
\hline Caspase- 9 & $\begin{array}{l}\text { F: TGTCCTACTCTACTTTCCCAGGTTTT } \\
\text { R: GTGAGCCCACTGCTCAAAGAT }\end{array}$ & XIAP & $\begin{array}{l}\text { F: GGGGTTCAGTTTCAAGGAC } \\
\text { R: TGCAACCAGAACCTCAAGTG }\end{array}$ \\
\hline $\mathrm{p} 53$ & $\begin{array}{l}\text { F: GCTCTGACTGTACCACCATCC-3' } \\
\text { R: CTCTCGGAACATCTCGAAGCG-3' }\end{array}$ & GAPDH & $\begin{array}{l}\text { F: CGGAGTCAACGGATTTGGTCGTAT-3 } \\
\text { R: AGCCTTCTCCATGGTGGTGAAGAC-3 }\end{array}$ \\
\hline
\end{tabular}

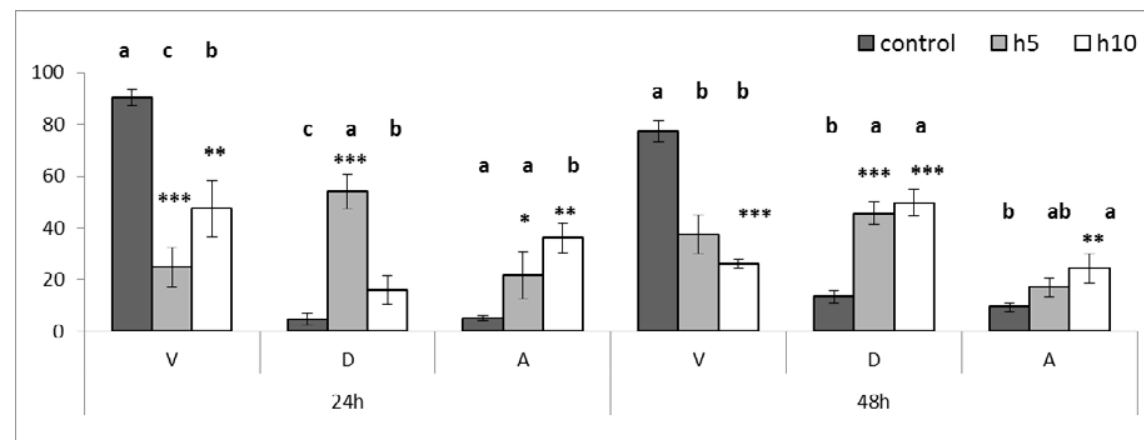

A

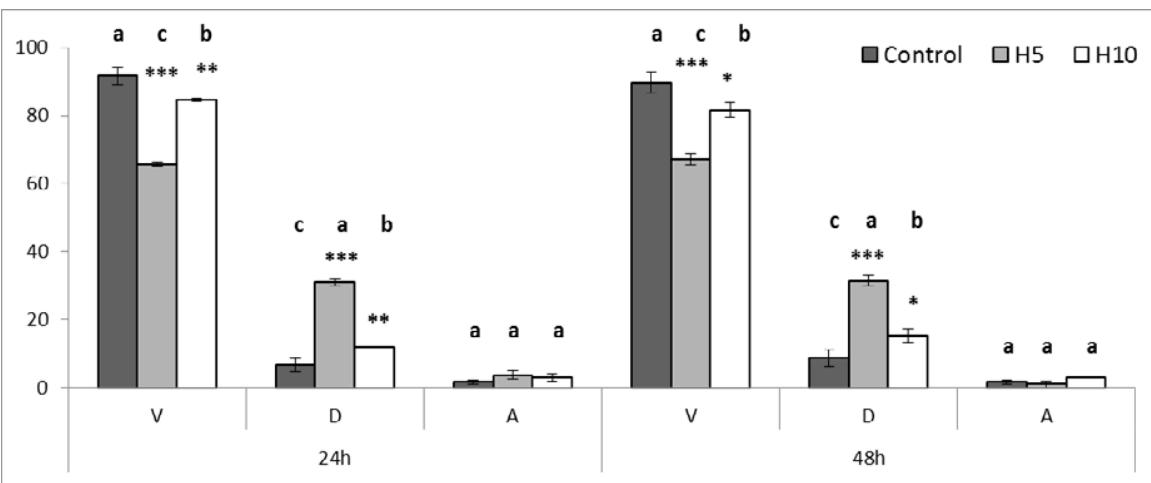

B

Figure 1. Effect of Hardaliye on HT-29 (a)and CF-1 (b) cell line after 24 h and 48 h of treatment (Tali Apoptosis assay). V: Viable, D: Dead, A: Apoptosis. H5 indicates Hardaliye which is diluted fivefold. H10 indicates Hardaliye which is diluted tenfold. Different letters in superscript indicate statistically significant differences between control and treatments. Data sets were normalized using arcsine square root transformation. Data are presented as mean \pm SDand show differences between control and treatments, $\mathrm{n}=3: * * * \mathrm{p}<0.001, * * \mathrm{p}<0.01,{ }^{*} \mathrm{p}<0.05$.

$2.3 \pm 0.15$-fold, casp 3; $2.0 \pm 0.27$-fold, casp2 were expressed after $24 \mathrm{~h}$ but casp9 when treated with H5. Even though Bcl-2 did not increase, the other apoptosis inhibitors, namely Survivin, XIAP, CIAP 1, CIAP 2 drastically increased. However, following $48 \mathrm{~h}$, gene expressions decreased. Conversely, H10 did not trigger DR4, DR5, Fas, cytc, p53, Bcl-2 and Bax but casp 3 and casp 2 after 24h, however, Bcl-2 increased
(1.7 \pm 0.05 -fold) after $48 \mathrm{~h}$. The other apoptosis inhibitors also increased while only CIAP 2 and casp 2 slightly decreased (Figures 4 and 6) as compared to respective controls.

The second step was to observe gene expression levels of ROS (reactive oxygen species) neutralizers. H5 triggered none of expression 


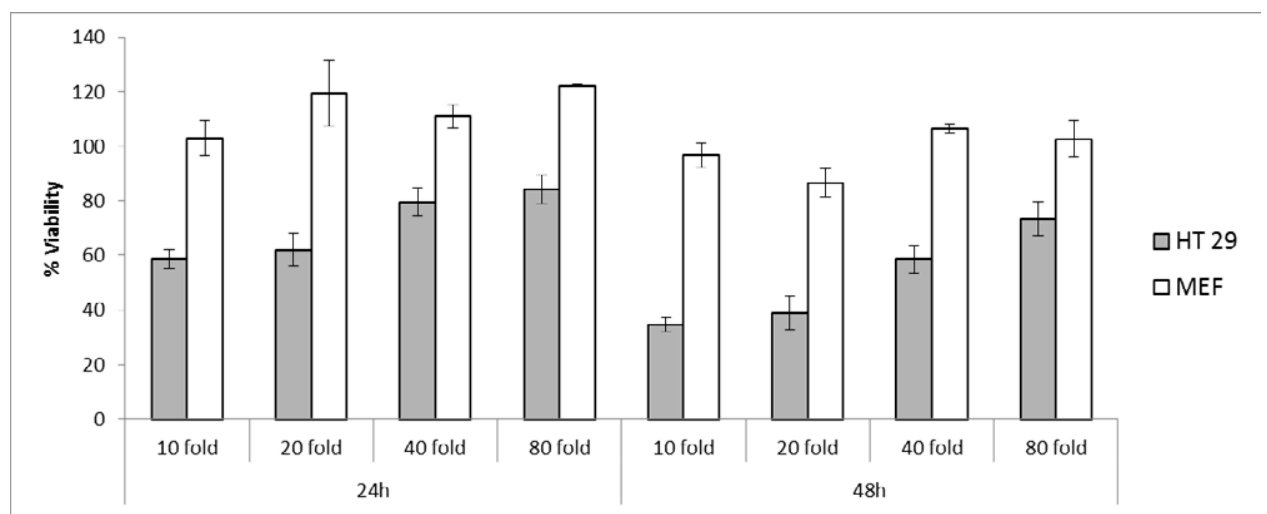

Figure 2. The viability (\%) analysis with MTT assay on HT-29 and CF-1 (MEF). Data are presented as mean \pm SD, $\mathrm{n}=3$.

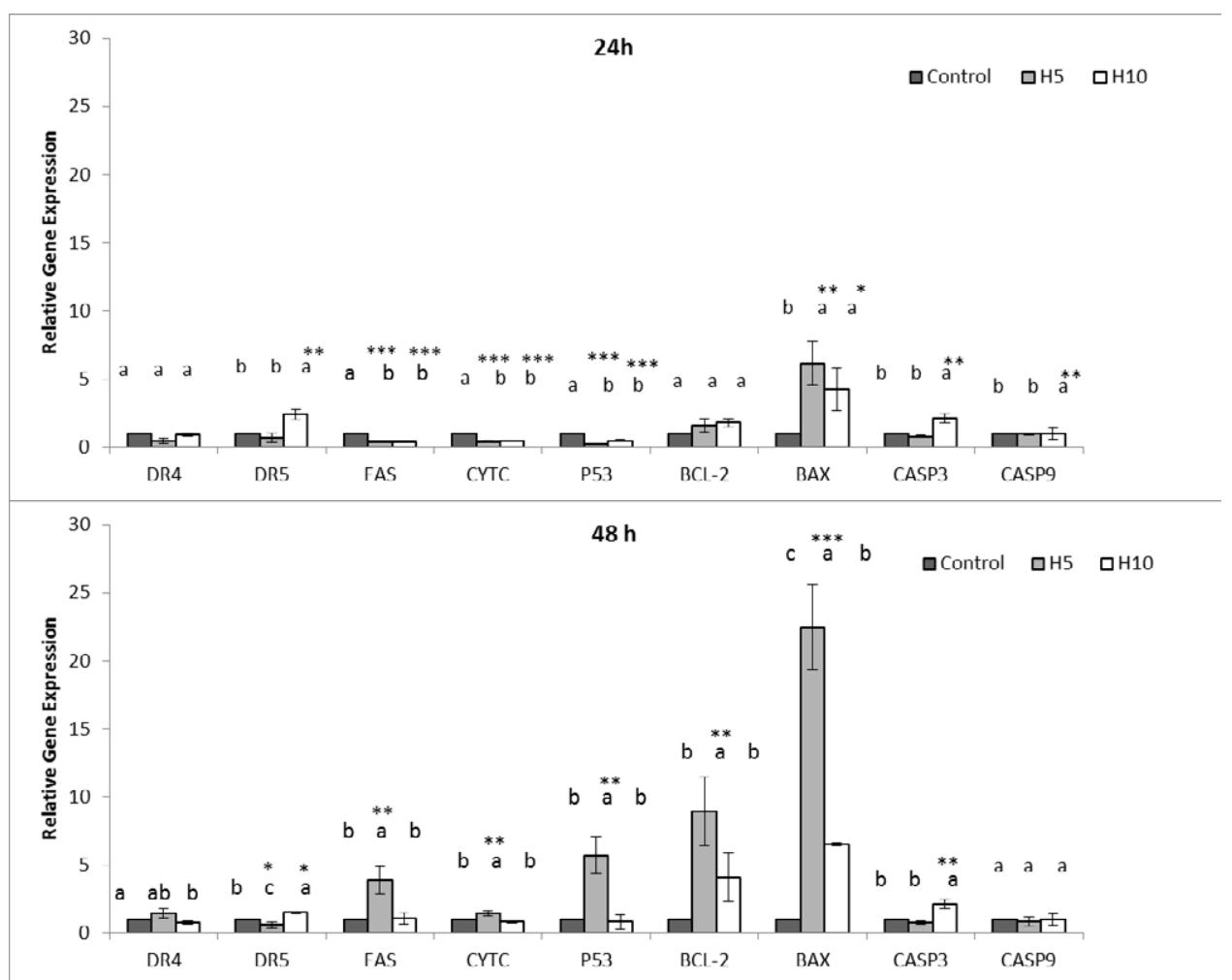

Figure 3. Effect of Hardaliye on apoptosis pathway related relative gene expressions of HT-29 cell line after $24 \mathbf{~ h}$ and 48 h of treatment. H5 indicates Hardaliye which is diluted fivefold. H10 indicates Hardaliye which is diluted tenfold. Different letters in superscript indicate statistically significant differences. Data are presented as mean \pm SD, $\mathrm{n}=3$ : $* * * \mathrm{p}<0.001$, $* * \mathrm{p}<0.01,{ }^{*} \mathrm{p}<0.05$.

of these enzymes after $24 \mathrm{~h}$ but a drastic increase of SOD and CAT was observed after $48 \mathrm{~h}$ but a mitochondrial Mn SOD2. However, as for CF-1 cells, although expression of antioxidant enzymes seems to increase after $24 \mathrm{~h}$, all decreased after $48 \mathrm{~h}$ but GpX expression of $\mathrm{H} 5$ treated cells (Figure 6). In addition, Hsp 70 level of H5 treated HT-29 cells remained low while H10 triggered it after $48 \mathrm{~h}$. CF-1 cells showed a opposite reaction and Hsp 70 decreased after $48 \mathrm{~h}$ which indicates probable diminishing of stress conditions in cells (Figure 6).

\section{Discussion and conclusions}

Anticancer activities of natural remedies, such as, plants, minerals and animals are of great interest since ancient times as an alternative cure. In fact, many antioxidant compounds derived from grape such as resveratrol have been screened for anticancer activity. Apart from these, this is the first report on anticancer activity of Hardaliye which is a traditional and lactic acid fermented beverage produced with mustard seed, cherry leaves and grape.

Cell proliferation results of Tali assays indicated that both $\mathrm{H} 5$ and H10 drastically decreased cell number. However, interestingly, H10 triggered apoptosis more than $\mathrm{H} 5$ which seems $\mathrm{H} 5$ can reveal an acute cytotoxicity. On the other hand, CF-1 cells were also affected slightly from $\mathrm{H} 5$ treatment but apoptosis levels were very low and equal to control. According to MTT assay, viability of HT-29 cells decreased even at 80 -fold dilution. CF-1 cells were not affected by treatment after $24 \mathrm{~h}$ and even Hardaliye stimulated proliferation. However, cell proliferation slightly decreased to a rate about $80-90 \%$ when treated with ten-fold and twenty-fold dilution after $48 \mathrm{~h}$. 
Ilkkan Kahraman O (2017) Anticancer activity of the "Hardaliye" on HT-29 Cell Line and proliferative activity on CF-1 cell line: Apoptosis and Antioxidant pathway responsive gene expressions

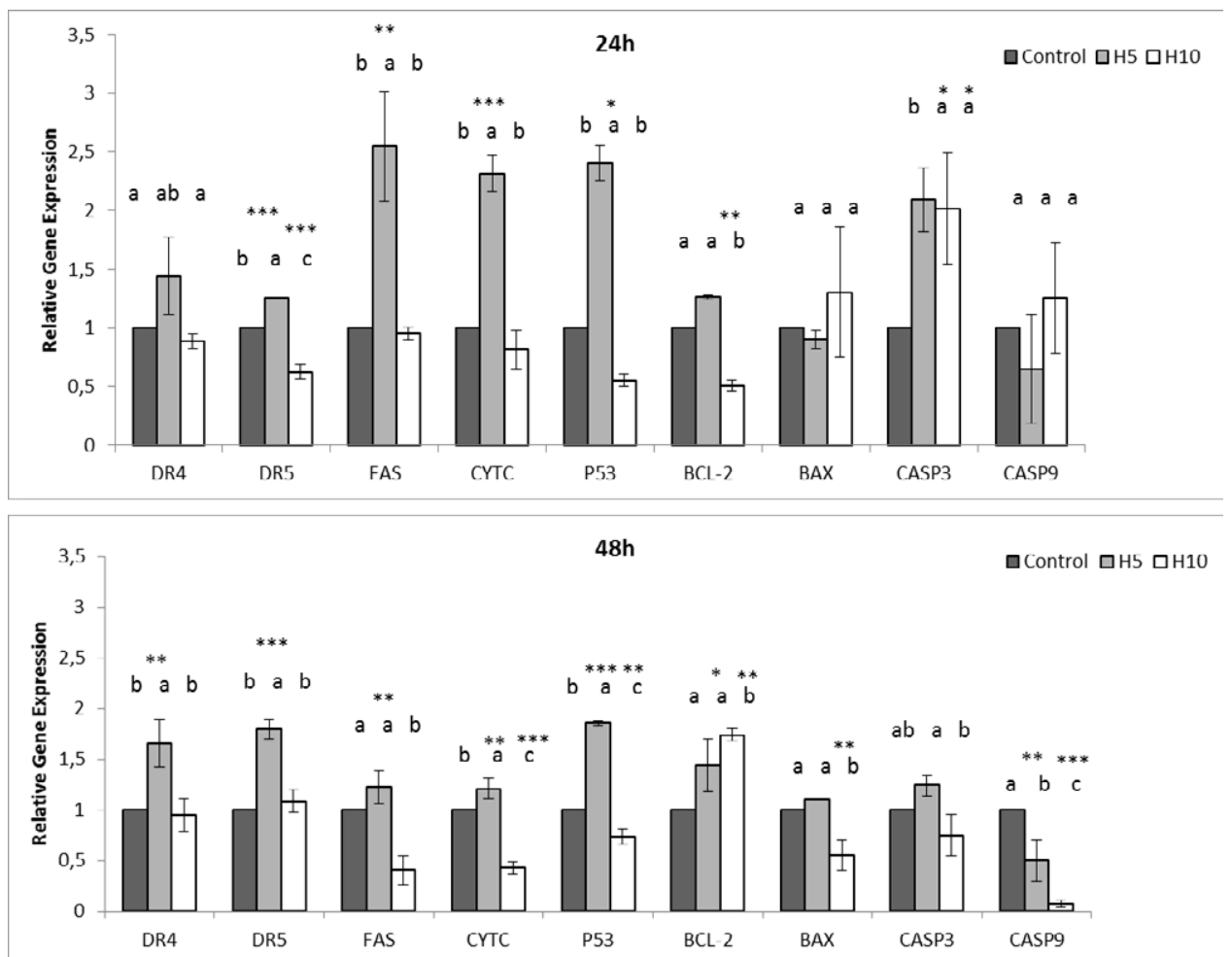

Figure 4. Effectof Hardaliye on apoptosis pathwayrelated relative gene expressions of CF-1 cell line after $\mathbf{2 4} \mathbf{h}$ and $\mathbf{4 8} \mathbf{h}$ of treatment. $\mathrm{H} 5$ indicates Hardaliye which is diluted fivefold. $\mathrm{H} 10$ indicates Hardaliye which is diluted tenfold. Different letters in superscript indicate statistically significant differences.Data are presented as mean $\pm \mathrm{SD}, \mathrm{n}=3: * * * \mathrm{p}<0.001, * * \mathrm{p}<0.01$, $* \mathrm{p}<0.05$.
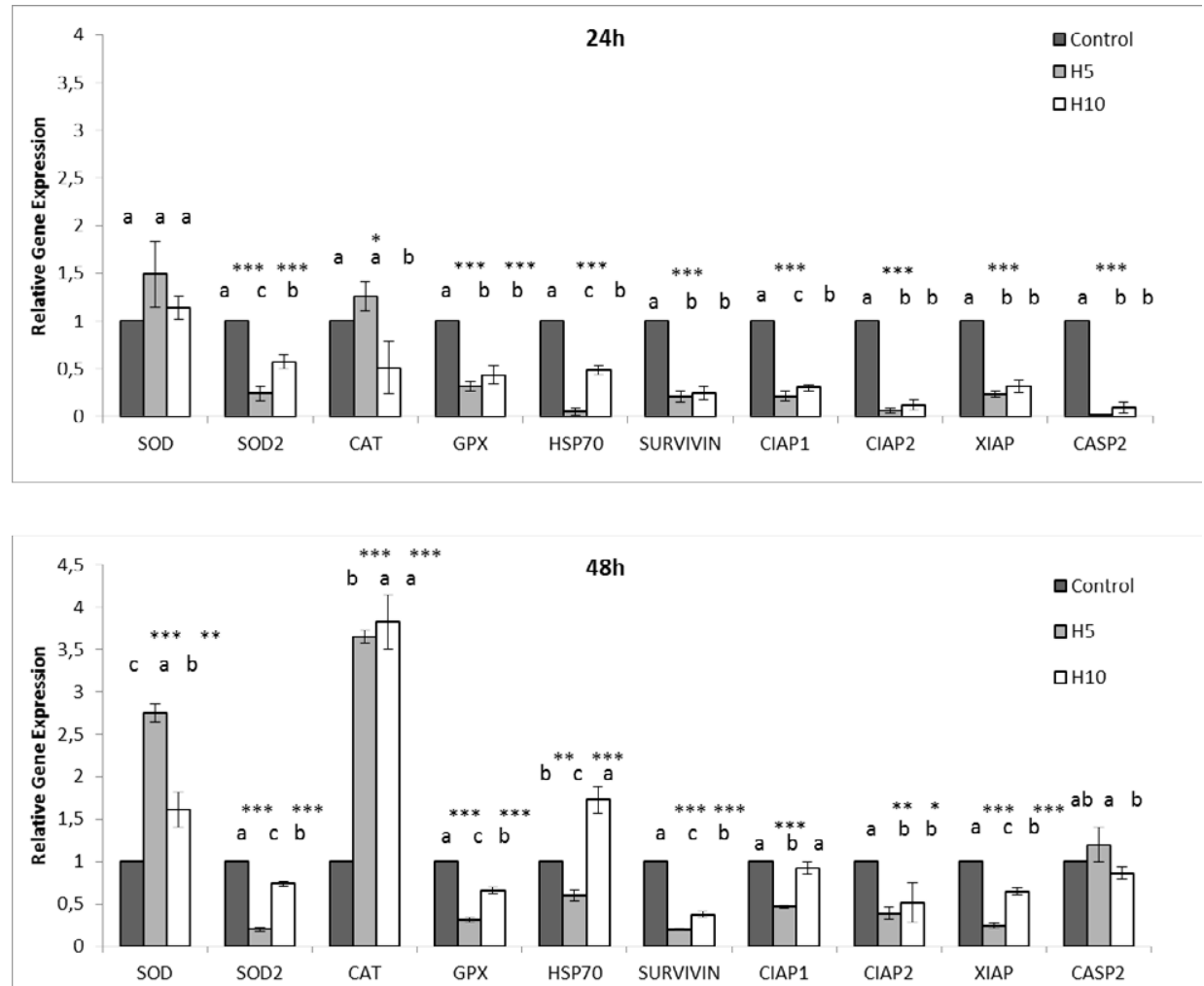

Figure 5. Effect of Hardaliye on apoptosis and antioxidant pathway related relative gene expressions of HT-29 after $24 \mathrm{~h}$ and $48 \mathrm{~h}$ of treatment. H5 indicates Hardaliye which is diluted fivefold. H10 indicates Hardaliye which is diluted tenfold. Different letters in superscript indicate statistically significant differences. Data are presented as mean \pm SD, $\mathrm{n}=3: * * *$ $\mathrm{p}<0.001,{ }^{* *} \mathrm{p}<0.01,{ }^{*} \mathrm{p}<0.05$. 
Ilkkan Kahraman O (2017) Anticancer activity of the "Hardaliye" on HT-29 Cell Line and proliferative activity on CF-1 cell line: Apoptosis and Antioxidant pathway responsive gene expressions
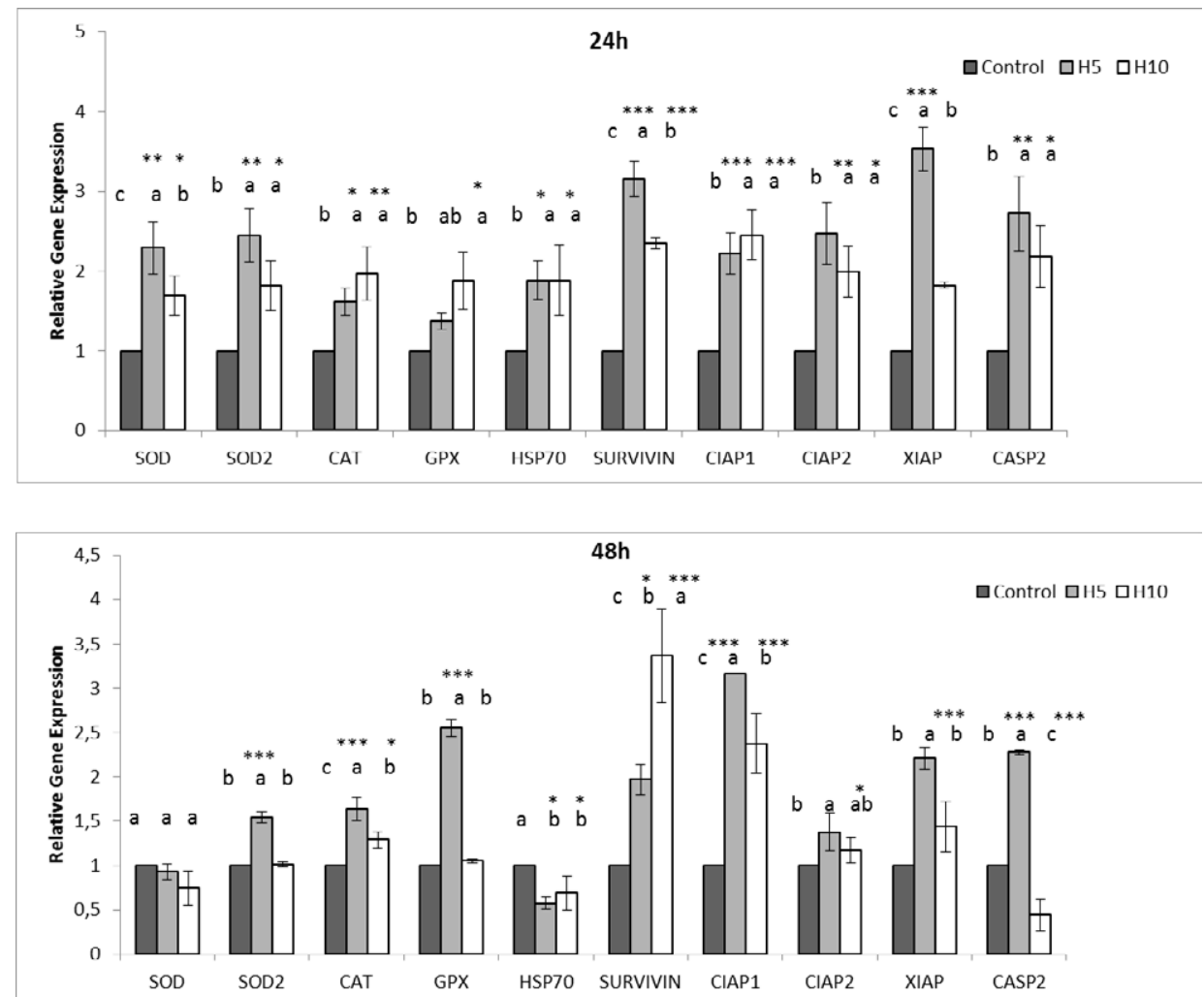

Figure 6. Effect of Hardaliye on apoptosis and antioxidant pathway related relative gene expressions of CF-1 after $24 \mathrm{~h}$ and $48 \mathrm{~h}$ treatment. $\mathrm{H} 5$ indicates Hardaliye which is diluted fivefold. H10 indicates Hardaliye which is diluted tenfold. Different letters in superscript indicate statistically significant differences. Data are presented as mean \pm SD, $\mathrm{n}=3: * * * \mathrm{p}<0.001$, $* * \mathrm{p}<0.01,{ }^{*} \mathrm{p}<0.05$

LC MS/MS analysis showed that Hardaliye mostly contained gallic acid and resveratrol. The rate of these polyphenols were consistent with studies conducted with grape juice or wine [28]. Gallic acid and resveratrol are polyphenols found in grape, tea, wine and berries. Their anti-aging, anticancer and anti-inflammatory effects have been demonstrated in vast variety of studies [29,30]. Digalloylresveratrol, a synthetic ester of gallic acid and resveratrol has been demonstrated that dose-dependently induces apoptosis and inhibites the transition from $S$ to G2/M phase of the HT-29 colon cancer cells [28]. Gallic acid has also induced apoptosis of colon adenocarcinoma cells [31]. On the other hand, gallic acid has also dose dependent pro-oxidant activity together with metals [32]. In accordance with this, in our results, H5 triggered expressions of SOD slightly more than H10 in healthy cells while the others were statistically equal. However, an antioxidant effect revealed after $48 \mathrm{~h}$ and expression levels decreased as expected but $\mathrm{GpX}$ expression of $\mathrm{H} 5$ still remained high, probably due to this above mentioned activity. However, HT-29 cells exhibit an expected contrary activity, SOD and especially CAT expression drastically increased thereby induced ROS-mediated apoptosis of cancer cells. Interestingly, $\mathrm{H} 5$ drastically triggered BAX activity and also p53, ctyc and Fas. On the other hand, H10 triggered DR5, BAX and casp3 which seems to cause apoptosis of HT-29 cells via p53 independent way.

Hsp 70 plays role in folding of misfolded proteins properly and protection of cells under stress condition. Its inhibition is a key factor to diminishment of cancer cells [18,20,21]. In this study, Hardaliye decreased HSP 70 level after $24 \mathrm{~h}$. As for $48 \mathrm{~h}$, HSP 70 level of $\mathrm{H} 5$ treatment remained still lower than control while $\mathrm{H} 10$ increased. However, this latter did not trigger apoptosis inhibitors such as Survivin.
Hardaliye contained mostly potassium and magnesium as well as some other antioxidant metals such as zinc and selenium. As mentioned above, some transition metals have also pro-oxidant capacity besides their antioxidant roles. The metals detected inside of Hardaliye either forced apoptosis effect together with polyphenols or exhibit prooxidant as mentioned before.

In the light of all the facts mentioned above, Hardaliye can be a good food support to prevent colon cancer. Furthermore, Hardaliye contains also a few kind of lactic acid bacteria and it has been demonstrated that lactic acid bacteria have anticancer activity on colon cancer [33]. However, even though this study tried to demonstrate and illuminate direct effect of Hardaliye on cells, bioavailability studies thereby observing absorption levels of these anticancer substances will help to clarify this research.

\section{Acknowledgments}

This project was supported by Research Fund of the Trakya University. Project Number: 2015-10.

\section{References}

1. Kaur M, Singh RP, Gu M, Agarwal R, Agarwal C (2006) Grape seed extract inhibits in vitro and in vivo growth of human colorectal carcinoma cells. Clin Cancer Res 12: 6194-6202. [Crossref]

2. Morré DM, Morré DJ (2006) Anticancer activity of grape and grape skin extracts alone and combined with green tea infusions. Cancer letters 238: 202-209. [Crossref]

3. Kaur M, Mandair R, Agarwal R, Agarwal C (2008) Grape seed extract induces cell cycle arrest and apoptosis in human colon carcinoma cells. Nutr Cancer 60 Suppl 1: 2-11. [Crossref] 
Ilkkan Kahraman O (2017) Anticancer activity of the "Hardaliye" on HT-29 Cell Line and proliferative activity on CF-1 cell line: Apoptosis and Antioxidant pathway responsive gene expressions

4. Alfaras I, Juan ME, Planas JM (2010) trans-Resveratrol reduces precancerous colonic lesions in dimethylhydrazine-treated rats. J Agric Food Chem 58: 8104-8110. [Crossref]

5. Aydoğdu H, Yıldırım, Ş, Halkman AK, Durgun T (2014) A study on production and quality criteria of hardaliye; a traditional drink from Thrace region of Turkey. Glda 39: $139-145$.

6. Altay F, Karbanc1oglu-Güler F, Daskaya-Dikmen C, Heperkan D (2013) A review on traditional Turkish fermented non-alcoholic beverages: microbiota, fermentation process and quality characteristics. Int J Food Microbiol 167: 44-56. [Crossref]

7. Arici M, Coskun F (2001) Hardaliye: fermented grape juice as a traditional Turkish beverage. Food microbiol 18: 417-421.

8. Fulda S, Debatin KM (2006) Extrinsic versus intrinsic apoptosis pathways in anticancer chemotherapy. Oncogene 25: 4798-4811. [Crossref]

9. Daniel PT, Wieder T, Sturm I, Schulze-Osthoff K (2001) The kiss of death: promises and failures of death receptors and ligands in cancer therapy. Leukemia 15: 1022 [Crossref]

10. Zhang, M., Harashima, N., Moritani, T., Huang, W. and Harada, M., 2015. The roles of ROS and caspases in TRAIL-induced apoptosis and necroptosis in human pancreatic cancer cells. PloS one 10: p.e0127386.

11. Hassanpour H, Teshfam M, Momtaz H, Zarei H, Bahadoran S (2014) Caspase-,--2, and-3 gene expression is enhanced in the heart and lung of chickens with pulmonary hypertension (ascites). Turkish J Veter Animal Sci 38: 133-137.

12. Chandra D, Liu JW, Tang DG (2002) Early mitochondrial activation and cytochrome c up-regulation during apoptosis. J Biol Chem 277: 50842-50854. [Crossref]

13. Wong RS (2011) Apoptosis in cancer: from pathogenesis to treatment. J Exp Clin Cancer Res 30: 87. [Crossref]

14. Kulbacka J, Saczko J, Chwilkowska A, Choromańska A, Skołucka N (2012) Apoptosis, free radicals and antioxidant defense in antitumor therapy. Antioxidant enzyme 265302 .

15. Wang Z, Sun Y (2010) Targeting p53 for novel anticancer therapy. Transl oncol 3: 1-12. [Crossref]

16. Hwang YJ, Lee EJ, Kim HR, Hwang KA (2013) In vitro antioxidant and anticancer effects of solvent fractions from Prunella vulgaris var. lilacina. BMC Complement Altern Med 13: 310. [Crossref]

17. Tinggi U (2008) Selenium: its role as antioxidant in human health. Environ Health Prev Med 13:102-108.

18. Hatfield MP, Lovas S (2012) Role of Hsp70 in cancer growth and survival. Protein Pept Lett 19: 616-624. [Crossref]

19. Thanan R, Oikawa S, Hiraku Y, Ohnishi S, Ma N, et al. (2014) Oxidative stress and its significant roles in neurodegenerative diseases and cancer. Int J mol sci 16: 193-217. [Crossref]

20. Goloudina AR, Demidov ON, Garrido C (2012) Inhibition of HSP70: a challenging anti-cancer strategy. Cancer Lett 325: 117-124. [Crossref]

21. Murphy ME (2013) The HSP70 family and cancer. Carcinogenesis 34: 1181-1188. [Crossref]

22. Agarwal C, Singh RP, Agarwal R (2002) Grape seed extract induces apoptotic death of human prostate carcinoma DU145 cells via caspases activation accompanied by dissipation of mitochondrial membrane potential and cytochrome c release. Carcinogenesis 23: 1869-1876. [Crossref]

23. Abaza MS, Orabi KY, Al-Quattan E, Al-Attiyah RJ (2015) Growth inhibitory an chemo-sensitization effects of naringenin, a natural flavanone purified from Thymus vulgaris, on human breast and colorectal cancer. Cancer Cell Int 15: 46. [Crossref]

24. Park SE, Yoo HS, Jin CY, Hong SH, Lee YW, et al. (2009) Induction of apoptosis and inhibition of telomerase activity in human lung carcinoma cells by the water extract of Cordyceps militaris. Food Chem Toxicol 47: 1667-1675. [Crossref]

25. Ho YT, Lu CC, Yang JS, Chiang JH, Li TC, et al. (2009) Berberine induced apoptosis via promoting the expression of caspase- $8,-9$ and-3, apoptosis-inducing factor and endonuclease G in SCC-4 human tongue squamous carcinoma cancer cells. Anticancer res 29: 4063-4070. [Crossref]

26. Livak KJ, Schmittgen TD (2001) Analysis of relative gene expression data using realtime quantitative PCR and the 2(-Delta Delta C(T)) Method. Methods 25: 402-408 [Crossref]

27. Miele A, Rizzon LA, Queiroz S, Gianello C (2015) Physicochemical composition, minerals, and pesticide residues in organic grape juices. Food Sci Technol (Campinas) 35: $120-126$.

28. Kala R, Tollefsbol TO, Li Y (2015) Potential of resveratrol in inhibiting cancer and slowing aging. J Nutri Food Sci (S15) 1.

29. Bernhaus A, Fritzer-Szekeres M, Grusch M, Saiko P, Krupitza G, et al. (2009) Digalloylresveratrol, a new phenolic acid derivative induces apoptosis and cell cycle arrest in human HT-29 colon cancer cells. Cancer letters 274: 299-304. [Crossref]

30. Udenigwe CC, Ramprasath VR, Aluko RE, Jones PJ (2008) Potential of resveratrol in anticancer and anti-inflammatory therapy. Nutr Rev 66: 445-454. [Crossref]

31. Yoshioka K, Kataoka T, Hayashi T, Hasegawa M, Ishi Y, et al. (2000) Induction of apoptosis by gallic acid in human stomach cancer KATO III and colon adenocarcinoma COLO 205 cell lines. Oncol rep 7: 1221-1224. [Crossref]

32. Verma S, Singh A, Mishra A (2013) Gallic acid: molecular rival of cancer. Environ Toxicol Pharmacol 35: 473-485. [Crossref]

33. Zhong L, Zhang X, Covasa M (2014) Emerging roles of lactic acid bacteria in protection against colorectal cancer. World J Gastroenterol 20: 7878-7886. [Crossref]

Copyright: (C2017 Ilıkkan Kahraman O. This is an open-access article distributed under the terms of the Creative Commons Attribution License, which permits unrestricted use, distribution, and reproduction in any medium, provided the original author and source are credited. 